\title{
Laemocharis ignicolor Ménétriés (Noctuidae, Arctiinae), a bogus neotropical moth
}

\author{
Vitor O. Becker ${ }^{1} \&$ Lívia R. Pinheiro²
}

\begin{abstract}
${ }^{1}$ Reserva Serra Bonita, P. O. Box 001, 45880-000 Camacan-BA, Brazil. becker.vitor@gmail.com
${ }^{2}$ Curso de Pós-Graduação em Ciências Biológicas (Zoologia), Instituto de Biociências, Museu de Zoologia, Universidade de São Paulo, Avenida Nazaré, 481, Ipiranga, 04263-000 São Paulo-SP, Brazil. 1rpinheiro@gmail.com
\end{abstract}

\begin{abstract}
Laemocharis ignicolor Ménétriés (Noctuidae, Arctiinae), a bogus neotropical moth. The identity of Laemocharis ignicolor Ménétriés, 1857 is established for the first time and is synonymized under Cosmosoma erythrarchos (Walker, 1854), syn. n.; lectotypes for L. ignicolor and L. vulnerata Herrich-Schäffer, [1854] are here designated.
\end{abstract}

KEYWORDS. Brazil; Euchromiina; synonymy; taxonomy.

RESUMO. Laemocharis ignicolor Ménétriés (Noctuidae, Arctiinae), uma falsa mariposa neotropical. A identidade de Laemocharis ignicolor Ménétriés, 1857 é estabelecida pela primeira vez e sinonimizada sob Cosmosoma erythrarchos (Walker, 1854), syn. n.; lectótipos para L. ignicolor e L. vulnerata Herrich-Schäffer, [1854] são aqui designados.

PALAVRAS-CHAVE. Brasil; Euchromiina; sinonímia; taxonomia.

Ménétriés (1857: 139) described Laemocharis ignicolor based apparently on a single specimen -it is very unlikely that he had more than one similar "bogus" specimen availablecollected by the Langsdorff expedition in "Minas Geraes", Brazil. However, as he did not explicitly indicate the number of specimens studied, the specimen which image was examined by the present authors is here designated as the lectotype. The species was never found again, despite frequent collecting in the region by numerous people. Hampson (1898: 185) transferred it to Sarosa Walker, but stated he had not seen the type material. Draudt (1915: 52) repeated Hampson's combination and redescribed the species; however, from his text it is doubtful that he examined any specimen either.

Examination of a colour image of the presumed type of $L$. ignicolor (Fig. 2) clearly shows that Draudt's figure (1915: pl. 11f) is inaccurate (showing almost no red). Close examination of that colour image (Fig. 2) suggests that the presumed type specimen consists of the head and thorax of a male specimen of Cosmosoma erythrarchos (Walker) (Fig. 1) and glued to it is the abdomen of a male specimen of Aethria haemorrhoidalis (Stoll) (Fig. 3). C. erythrarchos is endemic to the Brazilian Atlantic Forest. The senior author collected it at several localities in the region, including Nova Lima and Santa Bárbara (Caraça Monastery), both near Belo Horizonte in Minas Gerais State. A. haemorrhoidalis ranges from México to Brazil. A full synonymy of $C$. erythrarchos is presented below.

Abbreviations used in this work: BMNH, The Natural History Museum, London; MNHU, Museum für Naturkunde der Humbold-Universität, Berlin; ZI, Zoological Institute, Russian Academy of Sciences, St. Petersburg.

\section{Cosmosoma erythrarchos (Walker)}

Glaucopis erythrarchos Walker, 1854: 164. Holotype female, BRAZIL: [RJ, Rio de Janeiro] (H. Low) (BMNH) [examined].

Laemocharis vulnerata Herrich-Schäffer, [1854]: fig. 238. Lectotype male. [BRAZIL: RJ], Rio de Janeiro "Rio" (ZI), here designated [colour image examined]. Synonymized by Walker, 1856: 1607.

Lagaria vulnerata; Walker, 1856: 1607; Butler, 1877: 36, pl. 12, fig. 2.

Laemocharis ignicolor Ménétriés, 1857: 139, pl. 14, fig. 3. Lectotype male [BRAZIL]: MG "Minas Geraes", [1824] ([Ménétriés]) (ZI), here designated [colour image examined]. Kirby, 1892: 149. Syn. n.

Rezia erythrarchos; Kirby, 1892: 149; Watson, 1980: 169.

Sarosa ignicolor; Hampson, 1898: 185; Zerny, 1912: 57; Draudt, 1915: 52, pl. $11 \mathrm{f}$.

Cosmosoma erythrarchos; Hampson, 1898: 230; Zerny, 1912: 69; Draudt, 1915: 73, pl. $14 \mathrm{~m}$.

Remarks. Lagaria Walker (1854: 169) is a junior homonym of Lagaria Dallas, 1852 (Hemiptera) and Kirby (1892: 149) proposed Rezia as the objective replacement. It was synonymized with Cosmosoma Hübner, 1823 by Hampson (1898: 225), a treatment that was followed by all subsequent authors (Zerny 1912: 67; Draudt 1915: 71; Franclemont 1983: 119; Schmidt \& Opler 2008: 21). Cosmosoma sensu Hampson (1898: 225) is an assemblage of several groups, mostly unrelated, whose species should be grouped in a number of different genera. As a result a few of the generic names he listed in the synonymy should be revalidated. The second author is working on a classification of the group.

According to Komissarov (1988: 40-42), the Langsdorff expedition, of which Ménétriés was one of its members, left 

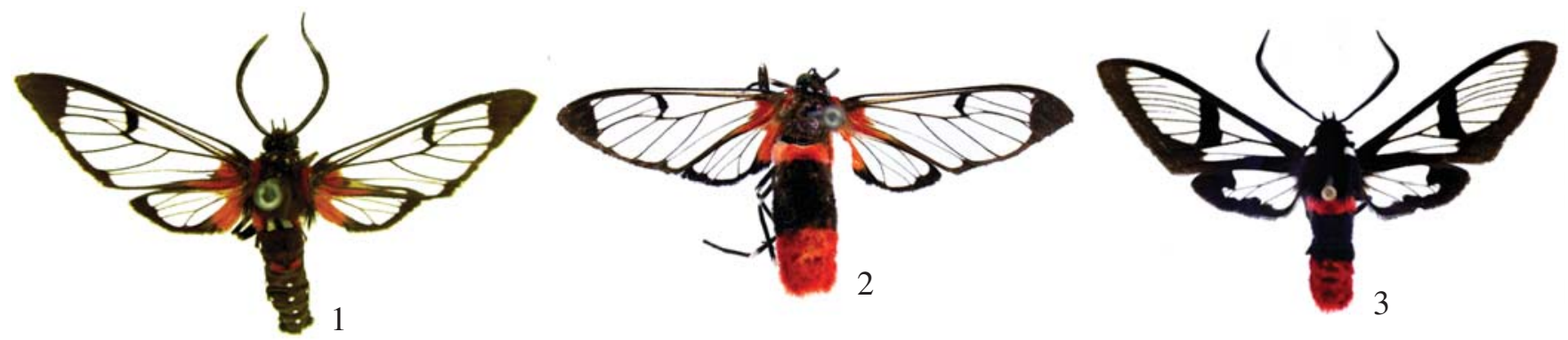

Figs. 1-3. 1, Cosmosoma erythrarchos (Walker) male (lectotype of Laemocharis vulnerata); 2, L. ignicolor Ménétriés, both parts male (type); 3, Aethria haemorrhoidalis (Stoll) male.

Rio de Janeiro for Minas Gerais in May, 1824 and returned at the beginning of 1825 . Most of this time was spent collecting around Ouro Preto, São João del Rei, and other mining localities in the region, including Serra [Monastery] do Caraça.

Laemocharis vulnerata was described from an unspecified number of specimens from the Kaden collection. According to Horn \& Kahle (1935-1937: 129), the exotic moths of that collection went to the Zool. Mus. Leningrad (ZI) via N. Ershoff. Dr. S. Sinev stated (pers. comm.) "I have found two specimens of Laemocharis vulnerata in our collection, and at least one of them should be the type figured by Herrich-Schäffer". This is the specimen designated here as lectotype (Fig. 1); the second is designated as paralectotype.

Walker (1856: 1607) considered L. erythrarchos to be a junior synonym of L. vulnerata. His and Herrich-Schäffer's works were contemporaneous, and the last was published in separate issues between 1852 and 1858. Fletcher (1979: xii) gives [1854] as the publication date of the plate containing fig. 238 , and in such cases, in order to establish priority, it should be regarded as [31.xii.1854]. According to Nye (1975: 6), the publication date of Walker's vol. 1 is 11.ii.1854.

Acknowledgements. Sergey Sinev (ZI) kindly sent colour images of the types of L. ignicolor and L. vulnerata, as well as other information about the specimens; Wolfram Mey (MNHU), provided information about the location of Herrich-Schäffer's types; M. Honey (BMNH) provided information about type material; A. Watson (BMNH) gave permission to the first author to study the collection; Anthony Raw, University of Santa Cruz, Ilhéus, Brazil, revised the text; Gerardo Lamas, Museo de Historia Natural, Lima, Peru, and an anonymous reviewer made several suggestions that improved the manuscript. This research was partially financed by Fundação de Amparo à Pesquisa do Estado de São Paulo (FAPESP), processes 2006/05362-4 and 2002/13898-0.

\section{REFERENCES}

Butler, A. G. 1877. Illustrations of typical specimens of Lepidoptera Heterocera in the British Museum 1: 1-62.

Draudt, M. 1915. Syntomidae, p. 33-230. In: A. Seitz (ed.). Die Gross-Schmetterlinge der Erde. V. 6. Stuttgart, Alfred Kernen.

Fletcher, D. S. 1979. Geometroidea. In: I. W. B. Nye (ed.). The generic names of the moths of the World. vol. 3, London, British Museum (Natural History), 243 p.

Franclemont, J. G. 1983. Arctiidae. In: R. W. Hodges (ed.). Check List of the Lepidoptera of America North of Mexico. London, E. W. Classey, 284 p.

Hampson, G. F. 1898. Catalogue of the Lepidoptera Phalaenae in the British Museum. vol. 1, London, British Museum (Natural History), 559 p.

Herrich-Schäffer, G. A. W. [1853-1858]. Sammlung neuer oder wenig bekannter aussereuropäischer Schmetterlinge. vol. 1, Regensburg, G. J. Manz., pls. 1- [96].

Horn, W. \& I. Kahle. 1935-1937. Über entomologische Sammlungen, Entomologen und Entomo-Museologie. Entomologische Beihefte aus Berlin-Dahlem 2-4: 1-536.

Kirby, W. F. 1892. A synonymic catalogue of LepidopteraHeterocera. London, Gurney \& Jackson, 951 p.

Komissarov, B. N. 1988. A expedição do acadêmico G. I. Langsdorff e seus artistas ao Brasil, p. 11-60. In: S. Monteiro \& L. Kaz (eds.). Expedição Langsdorff ao Brasil. vol.1, Rio de Janeiro, Alumbramento, $154 \mathrm{p}$.

Ménétriés, E. 1857. Enumeratio corporum animalium Musei Imperialis Academiae Scientiarum Petropolitanae. vol. 2, Petropoli, Eggers, 99-144 p.

Nye, I. W. B. 1975. The generic names of the moths of the World. vol. 1, London, British Museum (Natural History), 567 p.

Schmidt, B. C. \& P. A. Opler. 2008. Revised checklist of the tiger moths of the Continental United States and Canada. Zootaxa 1677: $1-23$.

Walker, F. 1854. List of specimens of lepidopterous insects in the collections of the British Museum 1: 1-278.

Walker, F. 1856. List of specimens of lepidopterous insects in the collections of the British Museum 7: 1509-1808.

Watson, A.; D. S. Fletcher \& I. W. B. Nye. 1980. Noctuoidea (part). In: I. W. B. Nye (ed.). The generic names of the moths of the World. vol. 2, London, British Museum (Natural History), 228 p. Zerny, H. 1912. Syntomidae. Lepidopterorum catalogus 7: 1-179. 